\title{
The Effects of Hours of Access to a Mixed \\ Ration on the Amount of Intake, Rate of \\ Eating and Probability of an Eating \\ Bout Continuing in Steers
}

\author{
Shigeru Morita and Susumu Nishino \\ Department of Dairy Science, Rakuno Gakuen \\ University, Ebetsu-shi 069
}

(Received June 29, 1992)

\begin{abstract}
The effects of hours of access to a mixed ration on the amount of intake and eating behavior in group-reared steers were studied. The rate of eating and probability of an eating bout continuing were compared, with different hours of access to the ration, for 4 steers. The dry matter intake/metabolic body size in $4^{-}, 6^{-}$and 12 -hour treatments was significantly $(\mathrm{P}<0.05)$ higher than that in a 2 -hour treatment. The time spent eating in a 4-hour treatment was significantly $(P<0.05)$ longer than that of a 2-hour treatment, and shorter than those of 6- and 12-hour treatments. The rate of eating in 2-and 4-hour treatments was greater than that in 6- and 12-hour treatments. The distribution of eating bouts in the 2 -hour treatment was non-random. The eating bouts were divided into 2 types, bout length less than or equal to 4 minutes (type $A$ ) and longer than 4 minutes (type B). The distribution of eating bouts in 4-, 6- and 12-hour treatments were random. The probability of the eating bout continuing in the 4-hour treatment was similar to that of type B in the 2-hour treatment, and significantly $(\mathrm{P}<0.05)$ higher than for 6- and 12-hour treatments. We concluded that for over 4 hours of access to a mixed ration, the probability of an eating bout continuing did not change, and that the probability of the eating bout continuing and rate of eating were increased by shortening the time of access to the ration.
\end{abstract}

Anim. Sci. Technol. (Jpn.) 64 (5): 448-454, 1993

Key words : hours of feed access, intake, rate of eating, eating bout, steers

Domestic animal performance is closely related to feed intake. It is important to study the eating behavior of animals in order to determine feed intake changes under various conditions.

Eating periods (meals) usually include short non-eating durations (within-meal intervals). These eating periods are separated by a long non-eating duration (inter-meal interval). An eating bout is the eating duration which separated by a within-meal interval. The time spent on actual eating that was separated by within-meal intervals ranged from 58 to $71 \%$ of the duration of meals that were separated by inter-meal intervals ${ }^{1,12,13)}$. For a detailed comparison of the time spent eating with feed intake, it might be necessary to use the eating bout length rather than the meal length.

There are few reports dealing with the distribution of an eating bout length in ruminants, in contrast to some other animals ${ }^{2,4,8,9)}$. In cattle, $\mathrm{METz}^{5)}$ studied the time patterns of eating behavior in order to create a model for eating behavior. There was no criterion for an 
eating bout under ad libitum conditions in his paper. However, we concluded that the criterion for an eating bout was 4 minutes in time-restricted conditions ${ }^{6}$. From this difference, we suggested that the existence of a criterion for eating bout was affected by hours of access to diet in the case of cattle ${ }^{7}$.

VASILATOS and WANGSNESS ${ }^{12)}$ suggested that feed intake in each meal was greater according to the duration of the meal for lactating cows fed a mixed ration ad libitum. The amount of feed intake during the meal was not only affected by the length of time spent eating, but also by increasing the rate of eating ${ }^{13)}$. The rate of eating increased and the time spent eating decreased, so eating behavior was lumped into a short feeding period ${ }^{3,10)}$ according to the shortening of the feeding access time. The high rate of eating in a shorter feeding period might be caused by longer meal length. There have been no reports dealing with meal length and the duration of access to a ration. In our previous study ${ }^{6}$, we defined the probability of an eating bout continuing in order to compare the continuance of eating behavior with the arrangement of feeding order.

The objectives of this study were to confirm tho effects of the duration of access to a ration on the existence of criteria for an eating bout, and then to determine the relationship between the rate of eating and continuance of eating behavior during the different durations of access to a ration.

\section{Materials and Methods}

4 Holstein steers were used, each about five months old, and $180 \mathrm{~kg}$ average live-weight at the start of this study. The steers were reared together in a dry lot with a feeding space. The steers were offered a mixed ration of pelleted concentrate $(54 \%)$ and chopped hay $(46 \%)$ twice daily $(7: 00$ and $19: 00)$. The chemical compositions of concentrate and hay are shown in Table 1. The duration that the steers had access to a ration at one offering were 2 hours,
Table 1. Chemical composition of feeds

\begin{tabular}{|c|c|c|c|c|}
\hline & $\begin{array}{l}\text { Dry } \\
\text { Matter }\end{array}$ & $\begin{array}{l}\text { Crude } \\
\text { Protein }\end{array}$ & $N D F^{1 !}$ & $\mathrm{ADF}^{21}$ \\
\hline Concentrate & $\begin{array}{c}96 \\
86.4\end{array}$ & $\overline{15.9} \%$ & $\begin{array}{c}\text { of DM } \\
14.2\end{array}$ & $\begin{array}{r}\text { asis- } \\
5.0\end{array}$ \\
\hline Hay & 86.9 & 17.0 & 50.6 & 30.5 \\
\hline
\end{tabular}

1) Neutral detergent fiber,

2) Acid detergent fiber

4 hours, 6 hours and 12 hours (2-hour, 4-hour, 6-hour and 12-hour treatments), respectively.

The amount of ration offered was greater than $110 \%$ of the amount of intake. The amount of intake was measured individually, with an individual allotment automatic feeder. The experimental periods lasted 10 days for each period of access to a ration. In the last two days of each experimental period, the starting and stopping times of eating were recorded. Eating started when steers put their head into the trough and began to eat the mixed ration. Eating stopped when steers finished chewing and swallowed the ration. However eating had not stopped when more eating followed swallowing.

The number of eating bouts $\left(\mathrm{N}_{\mathrm{i}}\right)$ longer than $t_{i}$ (eating bout length) was determined by the following exponential equation, with $N_{0}$ being the total number of eating bouts.

$$
N_{i}=N_{0} \exp \left(-b_{i} t_{i}\right)
$$

If the distribution of eating bouts fits with this theoretical exponential equation, the percentage of $N_{i}$ to $N_{0}$ (cumulative frequency) in expressed as $100 \exp \left(-b_{i} t_{i}\right)^{4)}$. When $b_{i}$ is constant, the relationship between eating bout length and the natural logarithm of cumulative frequency (log survivor function) is linear. The $\log$ survivor functions of each treatment are shown in Fig. 1. When the sample distribution of eating bouts is not fitted with theoretical distribution according to the KOLMOGOROV-SMIRNOV one-sample test ${ }^{7 "}$, the eating bouts are divided by their length for fitting with theoretical distribution.

The probability $\left(\mathrm{P}_{\mathrm{i}}\right)$ of an eating bout con- 
tinuing was determined from $100 \mathrm{~N}_{\mathrm{i}} / \mathrm{N}_{(\mathrm{i}-1)}$. If this equation is rearranged using equation (1) and $b_{i}$ is constant, $P_{i}$ is expressed as following equation ; $\mathrm{P}_{\mathrm{i}}=100 \exp \left(-1 / \mathrm{b}_{\mathrm{i}}\right)$. The statistical method for comparing the average between the different treatments was the WILCOXON ${ }^{-}$ MANN-WHITNEY two-sample test ${ }^{7}$.

\section{Results and Discussion}

Table 2 shows dry matter intake, the time spent eating and rate of eating for each period of access to a mixed ration. The amount of dry matter intake / metabolic body size in 4-, 6 - and 12-hour treatments was approximately the same, about $60 \mathrm{gDM} / \mathrm{kg}^{0.75}$, and significantly $(\mathrm{P}<0.05)$ higher than that in the 2 -hour treatment. The time spent eating in the 4hour treatment was significantly $(P<0.05)$ longer than in the 2-hour treatment, and significantly $(\mathrm{P}<0.05)$ shorter than in 6- and 12-hour treatments. The rate of eating was greater in 2- and 4-hour treatments than in 6and 12-hour treatments.

ERDMAN et al. ${ }^{3)}$ pointed out that milking cows that were offered total mixed diet during 4 hours of feed access tended to spend less time eating than during 6,8 and 10 hours of feed access, and that feed intake as a percentage of body weight was not affected by feed access time ranging from 4 hours to 10 hours. The results for the time spent eating and feed intake in this study agreed with theirs. The rate of eating increased in time-restricted feeding $^{(0)}$. This was the same result as in our study. We concluded than the time spent eating decreased and rate of eating in steers increased according to the time of access to a mixed ration under 4 hours, and feed intake decreased when under 2 hours of access to a mixed ration.

Fig. 1 shows the distribution of eating bouts. In the 2-hour treatment, the distribution of eating bouts did not fit with the theoretical distribution. The changing point of the eating bout distributions was chosen to be 4 minutes in the 2-hour treatment. The probability of an eating bout continuing was found to change with eating bout length of 4 minutes. Eating bouts were divided into two types, expressed as types A and B. Eating bout length was 4 minutes or less in the former and longer than 4 minutes in the latter. In 4-, 6- and 12-hour treatments, the distributions of eating bouts fitted with the theoretical distribution, and the probabilities of an eating bout continuing were not found to change with eating bout length. The cumulative frequency at 4 minutes was highest in the 4-hour treatment, and lowest in the 2-hour treatment.

In a previous study, we concluded that the probability of an eating bout continuing was constant in ad libitum conditions ${ }^{7}$, but was not constant in time-restricted conditions ${ }^{6)}$. The changing point that we chose was 4

Table 2. Dry matter intake, time spent eating and rate of eating in different hours of access to ration

\begin{tabular}{|c|c|c|c|c|}
\hline & \multicolumn{4}{|c|}{ time of access to mixed ration } \\
\hline & $2 \mathrm{hrs}$ & $4 \mathrm{hrs}$ & 6 hrs & $12 \mathrm{hrs}$ \\
\hline $\begin{array}{l}\text { Dry matter intake } \\
\left.\text { (DMg/feeding } / \mathrm{MBS}^{\prime \prime}\right)\end{array}$ & $51^{a} \pm 1$ & $60^{b} \pm 1$ & $61^{b} \pm 1$ & $60^{b} \pm 1$ \\
\hline $\begin{array}{l}\text { Time spent eating } \\
\text { (min./feeding) }\end{array}$ & $72^{a} \pm 4$ & $88^{b} \pm 5$ & $100^{c} \pm 8$ & $97^{c} \pm 3$ \\
\hline $\begin{array}{l}\text { Rate of eating } \\
\text { (DMg/min) }\end{array}$ & $40^{a} \pm 2$ & $39^{a} \pm 2$ & $32^{b} \pm 3$ & $33^{b} \pm 2$ \\
\hline
\end{tabular}




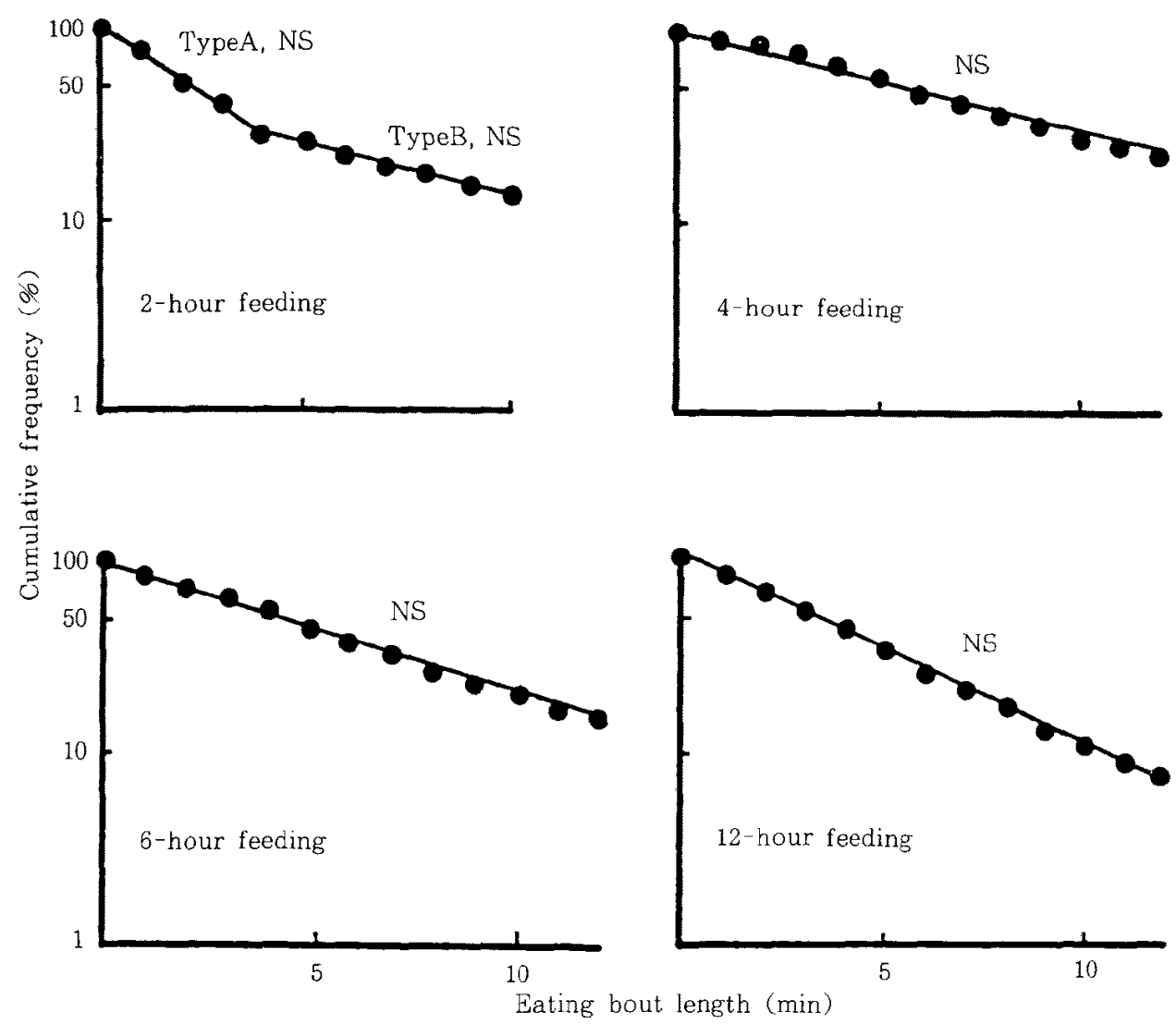

Fig. 1. Log survivor functions for eating bout lengths of steers for different times of mixed ration access. Each point gives the percentage of eating bouts longer than the length shown on the abscissa. NS indicates that the distribution of eating bout dose not differ from random distribution. Eating bout length of type $\mathrm{A}$ is equal to and shorter than 4 minutes, and of type $B$ is longer than 4 minutes.

minutes $^{6 /}$. In the present study, the distribution of eating bouts changed with eating bout length of 4 minutes when steers were offered a mixed ration for 2 hours. The result of the 2 -hour treatment was similar to the result of time-restricted feeding ${ }^{6}$. For $4-, 6-$ and $12-$ hour treatments, the distributions were random, and the probabilities of eating bout continuing were constant in this study. This was the same with the results of ad libitum feeding ${ }^{5,7)}$. Based on these results, we confirmed that the existence of criteria for an eating bout was affected by time of access to a ration and when steers were offered mixed ration over 4 hours a feeding, there was no criterion for an eating bout.

The frequency of eating bout, average of eating bout length and probability of an eating bout continuing are shown in Table 3 . The frequency of eating bout was significantly $(\mathrm{P}<$ 0.05 ) greater in 6- and 12-hour treatments than that in 2 - and 4 -hour treatments. The average eating bout length was significantly ( $P$ $<0.05)$ longer in the 4 -hour treatment than that in other treatments. The probability of an an eating bout continuing in an 4-hour 
Table 3. Frequency of eating bout, eating bout length and probability of eating bout continu continuing

\begin{tabular}{|c|c|c|c|c|}
\hline & \multicolumn{4}{|c|}{ time of access to mixed ration } \\
\hline & $2 \mathrm{hrs}$ & 4hrs & $6 \mathrm{hrs}$ & $12 \mathrm{hrs}$ \\
\hline $\begin{array}{l}\text { Frequency of eating bout } \\
\text { (numbers/feeding) }\end{array}$ & $12^{a} \pm 1$ & $11^{\mathrm{a}} \pm 1$ & $18^{b} \pm 1$ & $19^{b} \pm 3$ \\
\hline $\begin{array}{l}\text { Eating bout length } \\
\text { (min. bout) }\end{array}$ & $6.2^{a} \pm 0.3$ & $8.4^{6} \pm 1.1$ & $5.5^{c} \pm 0.2$ & $5.4^{c} \pm 0.6$ \\
\hline Probability" (96) & - & $87^{a} \pm 1$ & $83^{b} \pm 1$ & $82^{b} \pm 2$ \\
\hline Type $\mathrm{A}^{31}$ & $58 \pm 3^{21}$ & -5 & $-\cdots$ & - \\
\hline Type $B^{4 !}$ & $89 \pm 2$ & - & - & - \\
\hline
\end{tabular}

$a, b, c, P<0.05$

1) Probability of eating bout continuing.

2) Eating bouts were divided into 2 types.

3) Type A : Eating bout length shorter or eaqual to 4 minutes.

4) Type B: Eating bout length longer than 4 minutes.

5) Eating bouts were not divided.

treatment was similar to that of type $B$ in the 2 -hour treatment, and significantly $(P<0.05)$ higher than those in 6 - and 12 -hour treatments. The probability of eating bout continuing as a type $\mathrm{A}$ in the 2-hour treatment was lower than those in 4-, 6- and 12-hour treatments, and lower than that of type $B$ in the 2 -hour treatment.

The amount of feed intake in the meal increased by increasing the rate of eating according to extension of meal length ${ }^{13)}$. In accordance with decreasing the time of access to feed, eating behavior is lumped into short periods ${ }^{30}$ to maintain the amount of intake. Eating behavior length might be come longer by decreasing the time of access to feed. Using the probability of an eating bout continuing, we expressed the continuance of eating bout. In the 4-hour treatment, the rate of eating and probability of an eating bout continuing were higher than in 6 - and 12-hour treatments. It was suggested that the rate of eating increased due to raising the probability of an eating bout continuing in accordance with shortened access time to a ration over 4 hours.

In the 2-hour treatment, the probability of an eating bout of type $B$ was higher than that in 6-and 12-hour treatments, and similar to the 4-hour treatment. The cumulative frequency at 4 minutes in the 2-hour treatment was lowest. This indicated that the average eating bout length in the 2-hour treatment was shortened by decreasing the percentege of frequency of Type B bouts, and not by shortening the type bout length. We considered that in the very short duration of feed access likely in the 2 hour treatment, there was no more extension of eating bouts, but that frequency of shorter eating bouts increased in the intervals between longer eating bouts in order to maintain the amount of feed intake. There was no clear relationship between the rate of eating and the probability of an eating bout continuing, when eating bouts were divided into two types. Experiments in which time of access to a ration is under 2 hours are needed to confirm this point.

\section{Reference}

1) Chase, L.E., P.J. Wangsness and B.R. BAUMGard, Feeding behavior of steers fed a complete mixed ration. J. Dairy Sci., 59: 1923-1928. 1976.

2) Duncan, I.J.H., A.R. Horne, B.O. Hughes and D.S. Woon-Gush, The pattern of food intake in female Brown Leghorn fowls as recorded in a Skinner box. Anim. Behav., 
18: 245-255. 1970.

3) Erdman, R.A., T.W. Moreland and W.R. Stricklin, Effect of time of feed access on intake and production in lactating dairy cows. J. Dairy Sci., 72 : 1210-1216. 1989.

4) Levitsky, D.A., Feeding patterns of rats in response to fast and changes in environmental conditions. Physiol. Behav., 5: 291-300. 1970.

5) Metz, J.H.M., Time patterns of feeding and rumination in domestic cattle. Med Landbouwh. Wageningen, 75: 1-66. 1975.

6) Morita, S., M. Hirano and S. Nishino, Effect of arrangement of feeding order of diets on probability of eating bout continuing and frequency of eating bout in steers. Jpn. J. Livst. Management, 26 : 75-81. 1991.

7) Morita, S. and S. Nishino, Distribution of eating bouts and inter-bout intervals in steers offered mixed ration ad libitum. $J$. Rakuno Gakuen Univ., 16 : 21-25. 1991.

8) St.ATER, P.J.B., The temporal pattern of feeding in Zebra finch. Anim. Behav., 22 :
506-515. 1974 .

9) SteEL, R.G.D. and J.H. TorRie, Principles and procedures of statistics. 2nd ed. 533553. McGraw-Hill Book Company. New York. 1980

10) Suzuki, S., Y. Shinde and H. Hidart, Effects of a change in the daily time of access to hay on the rate of eating and feed intake of dairy cows. Jap. J. Zootech. Sci, , 41 : 423-429. 1970.

11) Thomas, D.W. and J. Mayer, Meal taking and regulation of food intake by normal and hypothalamic hyperphagic rats. J. Comp. Psychol., 66 : 642-653. 1968.

12) Vasilatos, $R$ and P.J. Wangsness, Feeding behavior of lactating dairy cows as measured by time-lapse photography. J. Dairy Sci., 63: 412-416. 1980.

13) Wangsness, P.J., L.E. Chase, A.D. Perterson, T.G. Hartsock, D.J. Kellmel and B.R. BAUMGARDT, System for monitoring feeding behavior of sheep. J. Anim. Sci., 42: 1544-1548. 1976. 


\title{
混合飼料の給与時間が去勢牛の採食量，採食速度 および採食継続確率に与える影響
}

\author{
森田 茂・西埜 進
}

酪農学園大学, 江別市 069

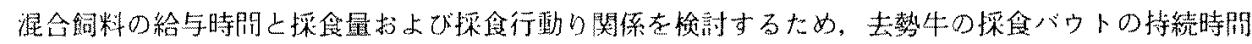
分布老調へ操食継続確率を求めた。供試動物には，ホルスタイン種去勢牛 4 頭を群飼し繰り这し川いた。

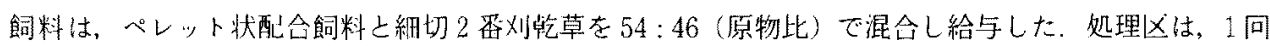

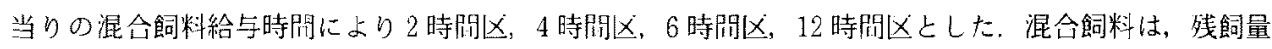
が給与量の $10 \%$ 以上となるように，上䛉給飼時間に従い，7:00および 19:00より給与した，各去勢

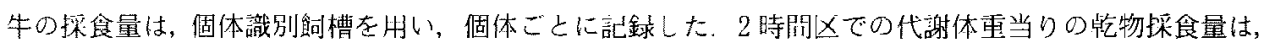

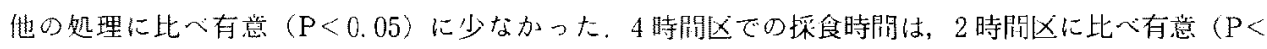

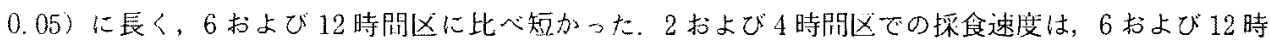

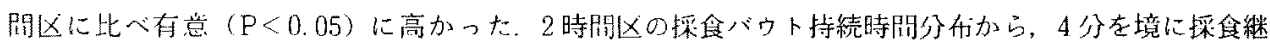

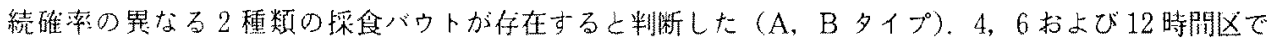

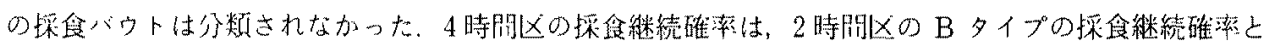

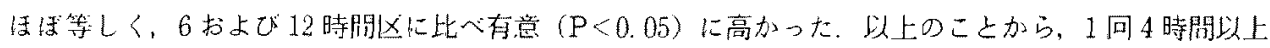
の飼料給与においては，持続時問による採食バウトの分類は行なわれないことが示された。また，採食 速度し操食継続確率との関連性が示唆された。
\end{abstract}

曰甾会報，64(5)：448-454，1993 